\title{
Evidence for a Cytosol Counterpart of the Major Plasma Membrane Protein in Acanthamoeba castellanii
}

\author{
By J. E. THOMPSON, T. MALER, J. A. CHAMBERS \\ AND J. A. WILKINS \\ Department of Biology, University of Waterloo, Ontario, Canada $\mathrm{N}_{2} L_{3} \mathrm{GI}_{\mathbf{I}}$
}

(Received 2 I September 1976)

\begin{abstract}
SUMMARY
Isolated plasma membranes from Acanthamoeba castellanii incorporated radioactivity when incubated in a corresponding labelled cytosol fraction. The incorporation increased linearly with time and reached saturation at high cytosol: membrane protein ratios in the incubation mixture. Polyacrylamide gel electrophoresis of treated membranes showed that the major protein, which comprised 40 to $50 \%$ of the total, was labelled, suggesting that it had exchanged with a radioactive cytosol counterpart. The same protein was discernible in polypeptide profiles of labelled cytosol and showed a higher specific radioactivity in the cytosol than in treated membranes. Inasmuch as it was not detached from the membrane by solutions of high ionic strength or chelation, this protein appears to be integral rather than peripheral.
\end{abstract}

\section{INTRODUCTION}

The plasma membrane of Acanthamoeba castellanii apparently lacks specialized transport sites since the amoebae depend solely on phagocytosis and pinocytosis to accumulate nutrients (Bowers \& Olszewski, 1972). A major consequence of this nutritional dependence on endocytosis is the expenditure of large amounts of surface membrane which must ultimately be replaced. This appears to involve turnover of plasma membrane at two levels: cycling of membrane which enables replacement of expended surface membrane without de novo synthesis; and turnover at the molecular level involving input of newly synthesized material (Goodall, Lai \& Thompson, 1972). In this study we have investigated the nature of plasma membrane turnover in $A$. castellanii by examining in vitro the molecular interaction between plasmalemma and cytosol.

\section{METHODS}

Plasma membrane isolation. Purified plasma membranes were isolated as described by Schultz \& Thompson (1969). This procedure has since been shown to compare favourably with an alternative method developed by Ulsamer et al. (1971) for Acanthamoeba. Cultures to be used for plasma membrane isolation were grown in 21 Erlenmeyer flasks containing I 1 optimal growth medium; 6 to 81 were used for a single preparation.

Treatment of membranes with labelled cytosol. Isolated plasma membranes were treated with ${ }^{14} \mathrm{C}$-labelled or ${ }^{125} \mathrm{I}$-labelled cytosol to determine whether some of the membrane proteins have soluble cytoplasmic counterparts with which they can exchange. To obtain ${ }^{14} \mathrm{C}$-labelled cytosol, amoebae were grown for $48 \mathrm{~h}$ in two $250 \mathrm{ml}$ Erlenmeyer flasks containing $100 \mathrm{ml}$ optimal growth medium and $50 \mu \mathrm{Ci}$ of a ${ }^{14} \mathrm{C}$-labelled algal hydrolysate amino-acid mixture (specific activity 57 to $60 \mathrm{mCi}$ per matom carbon; Amersham/Searle, 
Arlington Heights, Illinois, U.S.A.). The amoebae were harvested by centrifuging at $800 \mathrm{~g}$ for $10 \mathrm{~min}$, washed in $0.1 \mathrm{M}$-phosphate buffer $\mathrm{pH} 7.5$ and homogenized in $5 \mathrm{ml} \mathrm{I} \mathrm{mM-}$

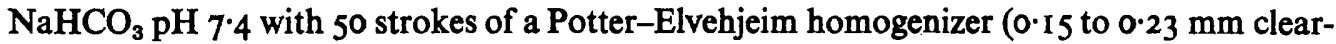
ance, rotating at $\left.\mathrm{I} 700 \mathrm{rev} . \mathrm{min}^{-1}\right)$. The homogenate was diluted to $10 \mathrm{ml}$ with the $\mathrm{NaHCO}_{3}$ solution and centrifuged at $140000 \mathrm{~g}$ for $3 \mathrm{~h}$ to yield cytosol and a pellet. The cytosol was collected with a syringe.

In other experiments, the cytosol was labelled with ${ }^{225}$ I after isolation using lactoperoxidase (Marchalonis, 1969; Marchalonis, Cone \& Santer, 197I). The iodination reaction mixture comprised (in a total volume of $7.3 \mathrm{ml}$ ): $6 \mathrm{ml}$ cytosol fraction; $720 \mathrm{nmol} \mathrm{KI}$; $9 \mu \mathrm{mol} \mathrm{H}_{2} \mathrm{O}_{2} ; 55$ i.u. lactoperoxidase (Calbiochem); and $780 \mu \mathrm{Ci}{ }^{125} \mathrm{I}$ (specific activity $>$ I $4 \mathrm{mCi}$ per $\mu \mathrm{g} \mathrm{I}$; Amersham/Searle). The reaction reached equilibrium after about $5 \mathrm{~min}$, and was stopped after $20 \mathrm{~min}$ by adding $0.15 \mathrm{ml} 83 \mathrm{mM}$-cysteine solution. Parallel controls were also run in which cysteine was present throughout to inhibit any iodination of protein.

Isolated plasma membranes were treated with either ${ }^{14} \mathrm{C}$-labelled or ${ }^{125} \mathrm{I}$-labelled cytosol for $15 \mathrm{~min}$ at $30^{\circ} \mathrm{C}$ in $0.05 \mathrm{M}$-Tris/ $\mathrm{HCl} \mathrm{pH} \mathrm{7.5}$. The cytosol fraction and a mixture of Tris and plasma membranes were equilibrated separately for 10 min at $30^{\circ} \mathrm{C}$ before being combined. Total reaction volumes and concentrations of membrane and cytosol for each experiment are specified in the figure legends. After incubation the mixture was diluted with an equal volume of ice-cold I mM-NaHCO $\mathrm{pH}_{7} \cdot 4$ and centrifuged at $48000 \mathrm{~g}$ for $30 \mathrm{~min}$. The pellet was resuspended in an equal volume of $\mathrm{NaHCO}_{3}$, centrifuged at $48000 \mathrm{~g}$ for $15 \mathrm{~min}$ and resuspended again in the same volume of $\mathrm{NaHCO}_{3}$. This suspension was twice frozen in dry ice/acetone and thawed before a final centrifugation at $48000 \mathrm{~g}$ for $\mathrm{I} 5 \mathrm{~min}$.

Radioactivity measurements and gel electrophoresis. Membranes treated with ${ }^{14} \mathrm{C}$-labelled cytosol were counted directly. The final pellet of washed membranes was resuspended in I to $2 \mathrm{ml} \mathrm{I} \mathrm{mM-NaHCO}{ }_{3} \mathrm{pH} 7.4$ and $100 \mu 1$ of this suspension was mixed with $0.5 \mathrm{ml}$ of NCS tissue solubilizer in a scintillation vial. Ten $\mathrm{ml}$ scintillation cocktail $(7 \mathrm{~g}$ PPO per 1 toluene) and $50 \mu \mathrm{l}$ ascorbic acid $(4 \%, w / v)$ were added. The samples were stored in the dark for 24 to $48 \mathrm{~h}$ and then counted with a Beckman LS-3 scintillation counter. In some experiments, membranes which had been treated with ${ }^{14} \mathrm{C}$-labelled cytosol were lipid-extracted with chloroform/methanol (2:1) as previously described (Korn \& Wright, 1973) to determine the distribution of ${ }^{14} \mathrm{C}$ between lipid and non-lipid components.

Membranes treated with ${ }^{125}$ I-labelled cytosol were solubilized and electrophoresed on $10 \%$ gels as previously described (Wilkins \& Thompson, 1974) except that 90 to $100 \mu \mathrm{g}$ protein was applied to the gels. After staining with Coomassie blue and scanning at $570 \mathrm{~nm}$, the gels were sliced into $\mathrm{I} \mathrm{mm}$ sections and counted in a Nuclear Chicago gamma counter. The protein stain did not interfere with the gamma counting so it was possible to get a protein scan and a radioactivity profile for the same gel. Polypeptide and radioactivity profiles were obtained for ${ }^{125} \mathrm{I}$-labelled cytosol in the same manner.

Treatment of membranes with $\mathrm{KCl}$ and EDTA/mercaptoethanol. The isolated membranes were treated with either $3 \mathrm{M}-\mathrm{KCl}$ in $5 \mathrm{mM}-\mathrm{Tris} / \mathrm{HCl} \mathrm{pH} 7.4$ or with a solution of $5 \mathrm{mM}$ EDTA and I mM- $\beta$-mercaptoethanol, $\mathrm{pH} 7 \cdot 4$, in an attempt to detach peripheral proteins. The treatment procedure described by Nicolson, Marchesi \& Singer (1971) was used, and the effects of the treatment were determined by electrophoresis of the membranes.

Enzyme and protein assays. Lactate dehydrogenase (EC I I I I .27) was assayed as described by Kolb, Fleischer \& Larner (1970) except that $0.15 \%(w / v)$ cholic acid was included in the assay mixture. Enzyme, buffer and cholic acid were pre-incubated for $30 \mathrm{~min}$ at room temperature before the reaction was started by adding NADH and pyruvate. This treatment makes membrane vesicles leaky (Archakov et al., 1974), and thus eliminates latent 


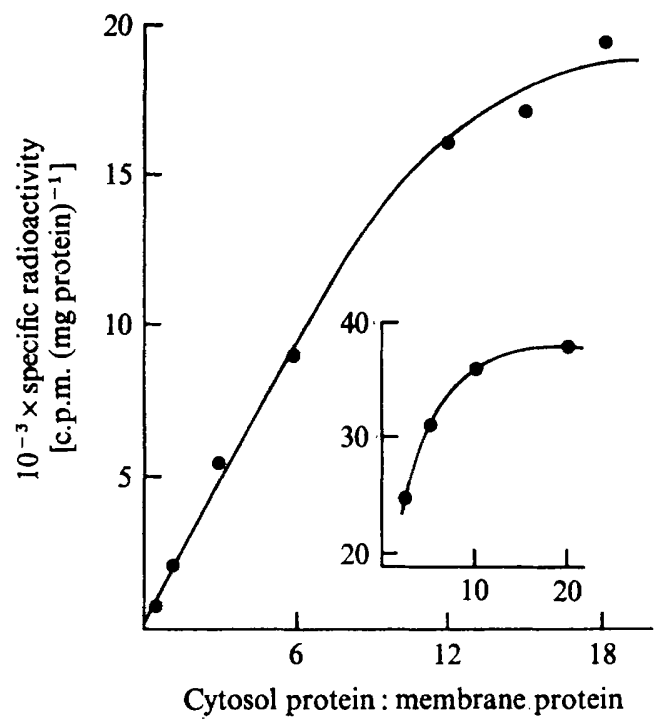

Fig. I. Changes in the specific radioactivity of plasma membrane incubated in mixtures containing different ratios of ${ }^{14} \mathrm{C}$-labelled cytosol protein to membrane protein. The main profile and the inset illustrate separate experiments. Each point is an average of duplicates in which $400 \mu \mathrm{g}$ membrane protein was treated for $15 \mathrm{~min}$ with sufficient cytosol to give the specified membrane protein:cytosol protein ratio in $5 \mathrm{ml}$ total vol.

enzyme activity which might otherwise not be detected. Measurements of lactate dehyrogenase in treated and untreated cytosol fraction where latency is not a problem showed that cholic acid has no effect on the activity of the enzyme per se.

Protein was measured by the method of Lowry et al. (I95I) using bovine serum albumin as a standard.

\section{RESULTS AND DISCUSSION}

Plasma membranes incubated for $15 \mathrm{~min}$ in ${ }^{14} \mathrm{C}$-labelled cytosol incorporated increasing amounts of radiactivity as the ratio of cytosol protein to membrane protein in the incubation mixture increased (Fig. I). Radioactivity profiles consistently showed a saturation plateau at values for the ratio ranging from 10 to 12 , but the specific radioactivities of the treated membrane at saturation varied among experiments. This variation presumably reflects differences in the specific radioactivity of the isolated cytosol fraction from experiment to experiment. The incorporation of ${ }^{14} \mathrm{C}$ radioactivity into the membrane fragments also increased linearly as a function of time over a period of at least $80 \mathrm{~min}$ under conditions in which the cytosol protein:membrane protein ratio was $18: 1$.

The ${ }^{14} \mathrm{C}$-labelled cytosol fraction was obtained by administering ${ }^{14} \mathrm{C}$-labelled amino acids to the growing amoebae, a procedure which labels protein primarily, but also other macromolecules including lipid. A major proportion (62 to $92 \%$ ), but not all, of the radioactivity incorporated into plasma membranes during their incubation in ${ }^{14} \mathrm{C}$-labelled cytosol was associated with non-lipid material. The variation in the proportion derives from adhesion of particulate material to the surfaces of the vessels used during the extraction procedure, which could not be removed by repeated rinsing with chloroform/methanol. Although the vessels were scraped, recovery was still incomplete, and this resulted in variation and presumably an underestimation of the radioactivity associated with non-lipid membrane components. 

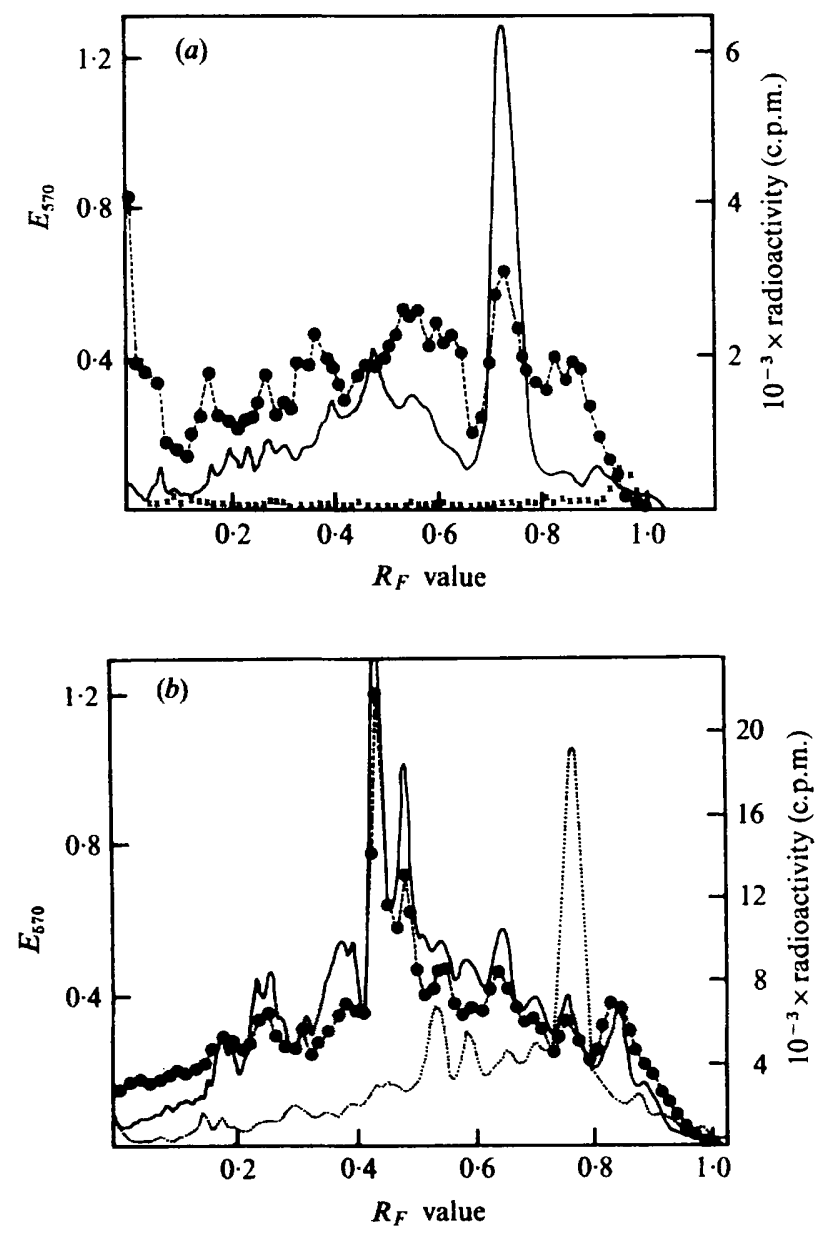

Fig. 2. Polyacrylamide gel electrophoresis scans and radioactivity profiles for plasma membrane and cytosol. (a) Membrane treated with ${ }^{125}$ I-labelled cytosol: $\mathrm{I} \cdot 28 \mathrm{mg}$ membrane protein was treated for $15 \mathrm{~min}$ with $20.4 \mathrm{mg}$ cytosol protein in $13.5 \mathrm{ml}$ total vol.,$- E_{570} ; 0---0,{ }^{125} \mathrm{I}$ radioactivity (c.p.m.) per gel slice; $x,{ }^{125}$ I radioactivity (c.p.m.) per gel slice for a control in which the membrane was treated with cytosol containing cysteine throughout the iodination reaction. (b) Iodinated cytosol. - $-E_{570} ;-0--0,{ }^{125}$ I-radioactivity (c.p.m.) per gel slice. $\cdots \cdots, E_{570}$ for untreated plasma membrane, included for comparison.

The saturation effect at high cytosol: membrane protein ratios, and the time dependence of the radioactivity incorporation, suggest some form of specific interaction between plasma membrane and the cytosol. The nature of this specificity with respect to protein was examined by electrophoresing cytosol-treated membrane and comparing patterns of radioactivity and protein distribution along the length of the gels. The membranes were incubated in iodinated cytosol rather than ${ }^{14} \mathrm{C}$-labelled cytosol to obtain higher specific activities for determination of radioactivity in the gel slices. The protein banding patterns for treated and untreated membrane were similar in that at least $50 \%$ of the total membrane protein ran as a single low molecular weight polypeptide with a $R$, value of 0.77 to 0.79 (Fig. 2a). The labelling of this protein in membranes treated with iodinated cytosol (Fig. $2 a$ ), implied that it had exchanged with a radioactive cytosol counterpart. In fact all the protein bands visible in the spectrophotometric scans for treated membranes appeared to be labelled. However, these 
Table I. Lactate dehydrogenase activity of homogenates, cytosol and plasma membrane fractions

The results of three experiments are given. Activities are expressed as nmol NADH oxidized $\mathrm{h}^{-1}$ (mg protein) ${ }^{-1}$.

$\begin{array}{cccc}\text { Homogenate } & \text { Cytosol } & \overbrace{\text { Unwashed }}^{\text {Plasma membrane }} & \text { Washed } \\ \text { I140 } & 2160 & 68.4 & 13 \cdot 2 \\ 1200 & - & 234 & 21.6 \\ - & 1860 & 57.6 & 18.0\end{array}$

other proteins were present in much lower relative proportions, and the correspondence between protein and radioactivity was definitive only for the major polypeptide. This major protein was not detached by $3 \mathrm{M}-\mathrm{KCl}$ or $5 \mathrm{mM}-\mathrm{EDTA} / \mathrm{I} \mathrm{mM}-\beta$-mercaptoethanol, indicating that it is an integral rather than peripheral protein. Treated membranes were washed thoroughly to remove cytosol contaminants by a procedure that included two successive freeze-thaw treatments. This washing reduced the specific activity of lactate dehydrogenase, a marker for cytosol, to less than $2 \%$ of that in homogenates and cytosol fractions (Table 1 ). Thus, contamination of the treated membrane by cytosol components presumably accounted for only minimal radioactivity.

Notwithstanding its integral character, the predominant protein of Acanthamoeba plasmalemma appears to have a soluble counterpart with which it can exchange, since it becomes labelled when isolated membrane is incubated in ${ }^{125}$ I-labelled cytosol. This interpretation is strengthened by the observation that the same protein $\left(R_{\boldsymbol{F}} 0.77\right)$ is present in the polypeptide profile of iodinated cytosol and appears to have a higher specific radioactivity in the cytosol than in treated membrane (compare Figs $2 a$ and $b$ ). Clearly the cytosol counterpart represents only a small proportion of the total soluble protein, but it registers distinctively and reproducibly in the profiles of cytosol protein and its relative mobility and molecular weight (approx. I5000 daltons) coincide with those of the major plasma membrane protein. This protein is a well established component of Acanthamoeba plasma membrane and the prospect of it being a proteolytic artefact has been ruled out (Korn \& Wright, 1973; Wilkins \& Thompson, 1974). Moreover, the presence of a corresponding protein with the same relative mobility and molecular weight in polypeptide profiles of homogenates and cytosol fractions from the amoebae has been noted previously, and again its presence in the homogenate cannot be attributed to proteolytic artefact since the protein banding patterns of homogenates taken before and after a $6 \mathrm{~h}$ incubation at $30^{\circ} \mathrm{C}$ are indistinguishable (Korn \& Wright, 1973).

The nutritional dependence of Acanthamoeba on endocytosis decrees that large amounts of plasma membrane be routinely turned over. Yet, Goodall et al. (1972) observed that incorporation of labelled precursors into the plasmalemma occurred to the same extent in both phagocytosing and non-phagocytosing amoebae. This was thought to reflect molecular turnover occurring independently of phagocytosis which may be necessary for routine maintenance of the membrane. This study supports the feasibility of molecular turnover by showing that at least the major protein of the plasma membrane has a cytosol counterpart despite its apparent integral character.

This work was supported by the National Research Council of Canada. 


\section{REFERENCES}

Archakov, A. I., Bachmanova, G. I., Devichensky, V. M., Karuzina, I. I., Zherebkova, N. S., Alimov, G. A., Kuznetsova, G. P. \& Karyakin, A. V. (1974). The reconstitution of microsomal redox chains. A comparative analysis of the effectiveness of membrane self-assembly and template binding of electron carriers. Biochemical Journal r44, I-9.

Bowers, B. \& OLSzeWSKI, T. E. (1972). Pinocytosis in Acanthamoeba castellanii. Journal of Cell Biology 53, $681-694$.

Goodall, R. J., LAI, Y. F. \& Thompson, J. E. (1972). Turnover of plasma membrane during phagocytosis. Journal of Cell Science II, 569-579.

Kolb, E., Fleischer, G. A. \& LARNER, J. (1970). Isolation and characterization of bovine lactate dehydrogenase. Biochemistry 9, 4372-4380.

KorN, E. D. \& WRight, P. L. (1973). Macromolecular composition of an amoeba plasma membrane. Journal of Biological Chemistry 248, 439-447.

Lowry, O. H., Rosebrough, N. J., FarR, A. L. \& Randall, R. J. (I95I). Protein measurement with the Folin phenol reagent. Journal of Biological Chemisty I93, 265-275.

Marchalonis, J. J. (1969). An enzymatic method for the trace iodination of immunoglobulins and other proteins. Biochemical Journal 1r3, 299-305.

Marchalonis, J. J., CONE, R. E. \& SANTER, V. (197I). Enzymatic iodination - a probe for accessible surface proteins of normal and neoplastic lymphocytes. Biochemical Journal 124, 92 I-927.

Nicolson, G. L., MARChesI, V. T. \& Singer, S. J. (I97I). The localization of spectrin on the inner surface of human red blood cell membranes by ferritin-conjugated antibodies. Journal of Cell Biology 5r, 265-272.

Schultz, T. M. G. \& Thompson, J. E. (1969). Enrichment of 5 -nucleotidase in membrane fragments isolated from Acanthamoeba sp. Biochimica et biophysica acta 193, 203-211.

Ulsamer, A. G., Wright, P. L., Wetzel, M. G. \& KorN, E. D. (197I). Plasma and phagosome membranes of Acanthamoeba castellanii. Journal of Cell Biology 51, 193-215.

Winkins, J. A. \& Thompson, J. E. (1974). The effects of cell population density on the plasma membrane of Acanthamoeba castellanii. Experimental Cell Research 89, 143-153. 